\title{
Facile Preparation and Functionalization of Chiral Stabilized Ylides From Common Chiral Auxiliaries Using Triphenylphosphoranylideneketene (the Bestmann Ylide) and their Use in Wittig Reactions
}

\author{
Robert K. Boeckman Jr., * Xinyi Song, and Joseph E. Pero \\ Department of Chemistry, University of Rochester, Rochester, NY 14627 \\ Supporting Information
}

\section{Table of Contents}

General Experimental Methods: .................................................. S2

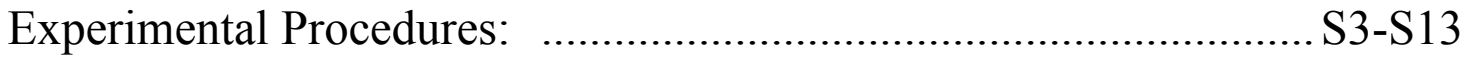

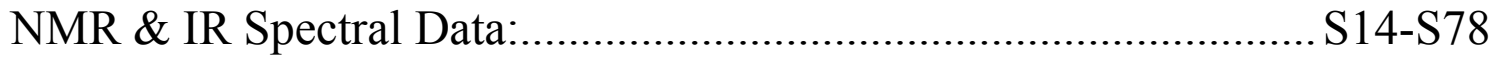




\section{General Experimental Methods}

All non-aqueous reactions were conducted in flame or oven-dried glassware under an argon (Ar) atmosphere and were stirred magnetically unless otherwise noted. Temperatures, other than room temperature, refer to bath temperatures unless otherwise indicated. The phrase "concentrated in vacuo" refers to removal of solvents by means of a rotary-evaporator attached to a water aspirator (15-30 Torr) followed by pumping to a constant weight $(<1$ Torr). Flash chromatography was performed on silica gel 60 (230400 mesh). Analytical thin layer chromatography (TLC) was performed using silica gel 60 F-254 pre-coated glass plates $(0.25 \mathrm{~mm})$. TLC Plates were analyzed by short wave UV illumination and/or by visualization with the specified stain and heating on a hot plate. Reagent-grade solvents were used without purification for all extractions and workup procedures. Deionized water was used for all aqueous reactions, work-ups, and for the preparation of all aqueous solutions. Reaction solvents were dried and purified according to published literature procedures by distillation under reduced pressure or Ar from an appropriate drying agent. Proton, carbon and phosphorus nuclear magnetic resonance (NMR) spectra were obtained on a $400 \mathrm{MHz}$ spectrometer. Chemical shifts are reported in ppm $(\delta)$ downfield from tetramethylsilane and are internally referenced to the deuterated solvent. ${ }^{1} \mathrm{H}$ NMR data are reported as follows: chemical shift (multiplicity, coupling constant $(\mathrm{Hz})$, number of hydrogens). Multiplicities are denoted accordingly: $\mathrm{s}$ (singlet), br s (broad singlet), d (doublet), br d (broad doublet), dd (doublet of doublets), ddd (doublet of doublet of doublets), dt (doublet of triplets), tt (triplet of triplets), dq (doublet of quartets), $\mathrm{t}$ (triplet), q (quartet), $\mathrm{p}$ (pentet), $\mathrm{m}$ (multiplet). Infrared spectra (IR) were acquired on a FT-IR and are reported in wavenumbers $\left(\mathrm{cm}^{-1}\right)$ with polystyrene as a standard. High resolution mass spectra were obtained using the following ionization techniques: chemical ionization (CI), electron impact (EI), and electrospray (ES). Optical rotation values were measured on a polarimeter. Samples were inserted into a cell with a path length of $1 \mathrm{dm}$. 


\section{Experimental Procedures}

Preparation of Ylides 13-15.

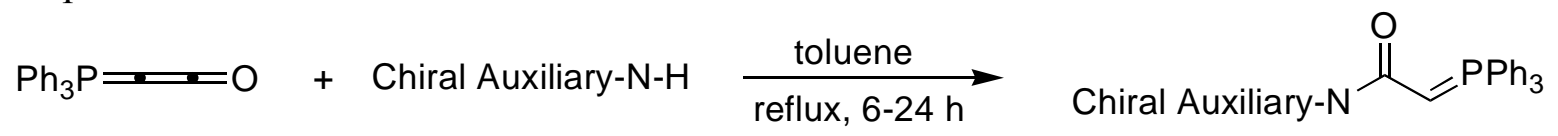

(1R, 4S)-4,5,5-Trimethyl-2-[2-(triphenylphosphanylidene)-acetyl]-2-azabicyclo[2.2.1]heptan-3-one (13).

According to the general procedure (see experimental section), ketene 5 ( $0.630 \mathrm{~g}, 2.08$ mmol, 1.5 equiv), and lactam $9(0.213 \mathrm{~g}, 1.39 \mathrm{mmol})$ were dissolved in $1 \mathrm{~mL}$ of anhydrous toluene and the resulting mixture heated until no more 9 could be detected by ${ }^{1} \mathrm{H}$ NMR (24 h). The solvent was removed in vacuo and the residue was triturated with $15 \mathrm{~mL}$ of a 10:1 mixture of hexane: $\mathrm{CH}_{2} \mathrm{Cl}_{2}$. The solvent was again removed in vacuo and the resulting solid residue was recrystallized from ethyl acetate at $-20^{\circ} \mathrm{C}$ affording $0.519 \mathrm{~g}$ of ylide $13(82 \%)$ as an off-white solid having mp $70-73{ }^{\circ} \mathrm{C},[\alpha]_{\mathrm{D}}{ }^{20}+2.2^{\circ}(\mathrm{c} 1.65$, $\mathrm{CH}_{2} \mathrm{Cl}_{2}$ ), and the following spectral characteristics: ${ }^{1} \mathrm{H} \mathrm{NMR}\left(400 \mathrm{MHz}, \mathrm{CDCl}_{3}\right) \delta 7.68$ $7.64(\mathrm{~m}, 6 \mathrm{H}), 7.53-7.50(\mathrm{~m}, 3 \mathrm{H}), 7.43-7.41(\mathrm{~m}, 6 \mathrm{H}), 4.84$ (d, J=20 Hz, 1H), 4.66 (br s, 1H), 1.74 (d, $J=8 \mathrm{~Hz}, 1 \mathrm{H}), 1.66-1.64(\mathrm{~m}, 3 \mathrm{H}), 1.12$ (s, 3H), 1.04 (s, 3H), 0.95 (s, 3H); ${ }^{13} \mathrm{C}$ NMR $\left(125 \mathrm{MHz}, \mathrm{CDCl}_{3}\right) \delta 178.4,165.2,133.2,131.9,128.8,127.4(\mathrm{~d}, J=91 \mathrm{~Hz})$, 57.7, 53.7, 45.5, 42.4, $39.8(\mathrm{~d}, J=119 \mathrm{~Hz}), 37.8,26.5,26.0,10.2 ;{ }^{31} \mathrm{P}$ NMR $(160 \mathrm{MHz}$, $\mathrm{CDCl}_{3}$ ) $\delta$ 14.6; IR (film) 2967, 2354, 2235, 1712, 1563, $1444 \mathrm{~cm}^{-1}$.

HRMS (EI). Calcd for $\mathrm{C}_{29} \mathrm{H}_{31} \mathrm{NO}_{2} \mathrm{P}(\mathrm{M}+\mathrm{H})^{+}$: 456.2087. Found: 456.2090.

\section{(S)-4-Benzyl-3-[2-(triphenylphosphanylidene)-acetyl]-oxazolidin-2-one (14). ${ }^{1}$}

According to the general procedure (see experimental section), ketene 5 (20.8 g, 0.069 mol, 1 equiv), and lactam 10 (12.2 g, 0.069 mol, 1 equiv) were disolved in $34 \mathrm{~mL}$ of anhydrous toluene and the resulting mixture heated until no more $\mathbf{1 0}$ could be detected by ${ }^{1} \mathrm{H}$ NMR (24 h). The solvent was removed in vacuo and the residue was recrystallized from ethyl acetate at $-20^{\circ} \mathrm{C}$ affording $28.0 \mathrm{~g}$ of ylide $14(85 \%)$ as a white solid having $\mathrm{mp}$ $156-158{ }^{\circ} \mathrm{C},[\alpha]_{\mathrm{D}}{ }^{20}+78.1^{\circ}$ (c $2.1, \mathrm{CH}_{2} \mathrm{Cl}_{2}$ ), and the following spectral characteristics: ${ }^{1} \mathrm{H}$ NMR (400 MHz, $\left.\mathrm{CDCl}_{3}\right) \delta$ 7.74-7.68 (m, 8H), 7.57-7.49 (m, 9H), 7.29-7.22 (m, 3H), 
$4.78(\mathrm{~d}, J=23 \mathrm{~Hz}, 1 \mathrm{H}), 4.78(\mathrm{~m}, 1 \mathrm{H}), 4.13-4.09(\mathrm{~m}, 1 \mathrm{H}), 4.04-4.02(\mathrm{~m}, 1 \mathrm{H}), 3.29(\mathrm{~d}, J=$ $13 \mathrm{~Hz}, 1 \mathrm{H}), 2.88-2.82(\mathrm{~m}, 1 \mathrm{H}) ;{ }^{13} \mathrm{C}$ NMR $\left(125 \mathrm{MHz}, \mathrm{CDCl}_{3}\right) \delta 165.1,155.1,136.6$, $133.2,133.1,132.2,129.7,128.9,128.7,128.6,127.4,126.8,65.0,54.9,39.6$ (d, $J=121$ $\mathrm{Hz}), 38.9 ;{ }^{31} \mathrm{P}$ NMR (160 MHz, $\left.\mathrm{CDCl}_{3}\right) \delta 1$. 1 ; IR (film) 3049, 2238, 1755, 1572, 1437 $\mathrm{cm}^{-1}$.

HRMS (EI). Calcd for $\mathrm{C}_{30} \mathrm{H}_{26} \mathrm{NO}_{3} \mathrm{P}(\mathrm{M}+\mathrm{H})^{+}: 480.1720$. Found: 480.1712 .

\section{(1R, 7S)-1-(10,10-Dimethyl-3,3-dioxo-thia-4-aza-tricyclo[5.2.1.0]dec-4-yl)-2- (triphenyl-phosphanylidene)-ethanone (15). ${ }^{2}$}

According to the general procedure (see experimental section), ketene 5 ( $0.670 \mathrm{~g}, 2.22$ mmol, 1.5 equiv), and sultam $11(0.319 \mathrm{~g}, 1.48 \mathrm{mmol})$ were disolved in $1.1 \mathrm{~mL}$ of anhydrous toluene and the resulting mixture heated until no more $\mathbf{1 1}$ could be detected by ${ }^{1} \mathrm{H}$ NMR $(6 \mathrm{~h})$. The solvent was removed in vacuo and the residue was triturated with $15 \mathrm{~mL}$ of a 10:1 mixture of hexane: $\mathrm{CH}_{2} \mathrm{Cl}_{2}$. The solvent was again removed in vacuo and the resulting solid residue was recrystallized from a 10:1 mixture of hexane:toluene at $-20^{\circ} \mathrm{C}$ affording $0.576 \mathrm{~g}(75 \%)$ of ylide 15 as a tan solid having $\mathrm{mp} 62-65^{\circ} \mathrm{C},[\alpha]_{\mathrm{D}}{ }^{20}-$ $4.4^{\circ}$ (c 11.4, $\mathrm{CH}_{2} \mathrm{Cl}_{2}$ ), and the following spectral characteristics: ${ }^{1} \mathrm{H}$ NMR $(400 \mathrm{MHz}$, $\left.\mathrm{CDCl}_{3}\right) \delta$ 7.66-7.63 (m, 6H), 7.53-7.51 (m, 3H), 7.45-7.42 (m, 6H), 3.89-3.87 (m, 1H), $3.77(\mathrm{~d}, J=17 \mathrm{~Hz}, 1 \mathrm{H}), 3.36(\mathrm{~d}, J=4 \mathrm{~Hz}, 2 \mathrm{H}), 2.13-2.11(\mathrm{~m}, 1 \mathrm{H}), 1.96-1.92(\mathrm{~m}, 1 \mathrm{H})$, $1.81(\mathrm{~d}, J=5 \mathrm{~Hz}, 3 \mathrm{H}), 1.25($ br s, $5 \mathrm{H}), 0.92(\mathrm{~s}, 3 \mathrm{H}) ;{ }^{13} \mathrm{C} \mathrm{NMR}\left(125 \mathrm{MHz}, \mathrm{CDCl}_{3}\right) \delta$ 164.7, 133.3, 132.1, 128.9, 127.0 (d, $J=91 \mathrm{~Hz}), 64.9,52.7,47.8,47.7,44.8,39.3$ (d, $J=$ $122 \mathrm{~Hz}$ ), 38.7, 32.5, 26.9, 20.9, 20.0; ${ }^{31} \mathrm{P}$ NMR (160 MHz, $\left.\mathrm{CDCl}_{3}\right) \delta 14.3$; IR (film) 2955, $1590,1478,1431 \mathrm{~cm}^{-1}$.

HRMS (EI). Calcd for $\mathrm{C}_{30} \mathrm{H}_{32} \mathrm{NO}_{3} \mathrm{PS}(\mathrm{M}+\mathrm{H})^{+}:$518.1913. Found: 518.1921. 
Alkylation of the Ylides 7, 12: Preparation of Ylides 16b-d and 17b-e

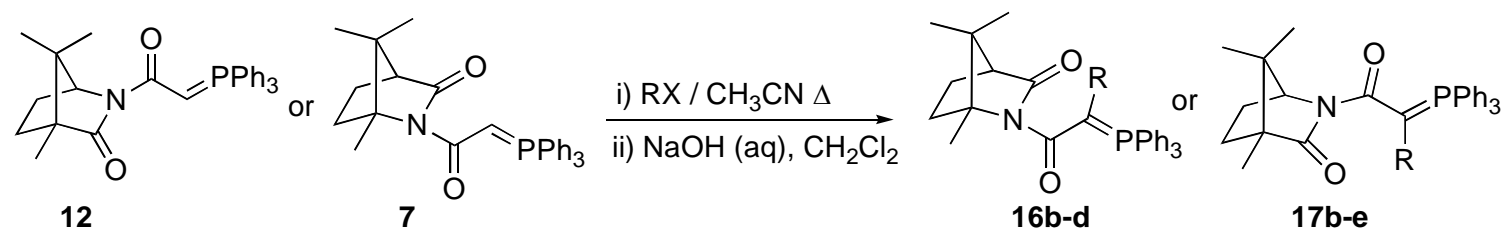

(1R, 4S)-1,7,7-Trimethyl-2-[2-(triphenylphosphanylidene)-propionyl]-2-aza-

\section{bicyclo[2.2.1] hept-an-3-one (16a).}

A mixture of ylide $7(227 \mathrm{mg}, 0.5 \mathrm{mmol})$ and methyl iodide $(0.062 \mathrm{~mL}, 142 \mathrm{mg}, 1$ mmol, 2.0 equiv) in $1 \mathrm{~mL}$ of anhydrous acetonitrile was heated to reflux. The resulting homogeneous mixture was kept at reflux for $2 \mathrm{~h}$. After that time, the reaction mixture was cooled to room temperature, concentrated in vacuo, and the residue redissolved in 2 $\mathrm{mL}$ of dichloromethane. A $1 \mathrm{~mL}$ portion of $1 \mathrm{M}$ aqueous $\mathrm{NaOH}$ (2.0 equiv) was added and the mixture was stirred vigorously at room temperature for $2 \mathrm{~h}$. The phases were separated aqueous phase was extracted twice with $2 \mathrm{~mL}$ of dichloromethane and the combined organic phases were dried over magnesium sulfate, and concentrated in vacuo to give a solid residue. This solid residue was purified by chromatography on $\mathrm{SiO}_{2}$ with elution with $50-100 \%$ ethyl acetate in hexane) to provide $0.230 \mathrm{~g}(98 \%)$ of ylide 16a as a white solid having mp $122-127{ }^{\circ} \mathrm{C}(\mathrm{dec})$ and spectral characteristics: ${ }^{1} \mathrm{H}$ NMR (400 $\left.\mathrm{MHz}, \mathrm{CDCl}_{3}\right)^{\text {Tм }} 7.68-7.63(\mathrm{~m}, 6 \mathrm{H}), 7.53-7.49(\mathrm{~m}, 3 \mathrm{H}), 7.45-7.41(\mathrm{~m}, 6 \mathrm{H}), 2.41-2.35(\mathrm{~m}$, 1H), $2.32(\mathrm{~d}, J=4 \mathrm{~Hz}, 1 \mathrm{H}), 1.98-1.90(\mathrm{~m}, 1 \mathrm{H}), 1.70-1.63(\mathrm{~m}, 2 \mathrm{H}), 1.59(\mathrm{~d}, J=16 \mathrm{~Hz}$, 3H), $1.32(\mathrm{~s}, 3 \mathrm{H}), 1.13(\mathrm{~s}, 3 \mathrm{H}), 0.87(\mathrm{~s}, 3 \mathrm{H}) ;{ }^{13} \mathrm{C} \mathrm{NMR}\left(125 \mathrm{MHz}, \mathrm{CDCl}_{3}\right){ }^{\text {тм }}$ 175.9, $167.7,133.7,131.6,128.6,126.6\left(\mathrm{~d}, J_{C-P}=113 \mathrm{~Hz}\right), 71.9,56.5,53.6\left(\mathrm{~d}, J_{C-P}=137 \mathrm{~Hz}\right)$, 49.0, 33.4, 24.2, 19.1, 18.1, 13.0, 12.2; IR (film) 2961, 2231, 1701, 1558, $1438 \mathrm{~cm}^{-1}$. HRMS (EI). Calcd for $\mathrm{C}_{30} \mathrm{H}_{33} \mathrm{NO}_{2} \mathrm{P}(\mathrm{M}+\mathrm{H})^{+}: 470.2249$. Found: 470.2255. 


\section{(1R, 4S)-1,7,7-Trimethyl-2-[2-(triphenylphosphanylidene)-octanoyl]-2-aza- bicyclo[2.2.1]heptan-3-one (16b).}

A mixture of ylide $7(228 \mathrm{mg}, 0.5 \mathrm{mmol})$ and 1-iodohexane $(0.148 \mathrm{~mL}, 212 \mathrm{mg}, 1$ mmol, 2.0 equiv) in $1 \mathrm{~mL}$ of anhydrous acetonitrile was heated to reflux. The resulting homogeneous mixture was kept at reflux for $2 \mathrm{~h}$. After that time, the reaction mixture was cooled to room temperature, concentrated in vacuo, and the residue redissolved in 2 $\mathrm{mL}$ of dichloromethane. A $1 \mathrm{~mL}$ portion of $1 \mathrm{M}$ aqueous $\mathrm{NaOH}$ (2.0 equiv) was added and the mixture was stirred vigorously at room temperature for $2 \mathrm{~h}$. The phases were separated aqueous phase was extracted twice with $2 \mathrm{~mL}$ of dichloromethane and the combined organic phases were dried over magnesium sulfate, and concentrated in vacuo to give a solid residue. This solid residue was purified by chromatography on $\mathrm{SiO}_{2}$ with elution with 50 - $100 \%$ ethyl acetate in hexane to provide $0.260 \mathrm{~g}(98 \%)$ of ylide $\mathbf{1 6 b}$ as a white solid having mp $167-170{ }^{\circ} \mathrm{C}$ and the following spectral characteristics: ${ }^{1} \mathrm{H}$ NMR $\left(400 \mathrm{MHz}, \mathrm{CDCl}_{3}\right) \delta$ 7.71-7.64 (m, 6H), 7.53-7.46 (m, 3H), 7.45-7.40 (m, 6H), 2.43-2.38 $(\mathrm{m}, 1 \mathrm{H}), 2.32(\mathrm{~d}, J=4 \mathrm{~Hz}, 1 \mathrm{H}), 2.08-1.91(\mathrm{~m}, 1 \mathrm{H}), 1.67-1.60(\mathrm{~m}, 2 \mathrm{H}), 1.43-1.40(\mathrm{~m}, 1 \mathrm{H})$, $1.36(\mathrm{~s}, 3 \mathrm{H}), 1.30-1.25(\mathrm{~m}, 1 \mathrm{H}), 1.09(\mathrm{~s}, 3 \mathrm{H}), 1.08-1.00(\mathrm{~m}, 4 \mathrm{H}), 0.98-0.89(\mathrm{~m}, 4 \mathrm{H}), 0.86$ $(\mathrm{s}, 3 \mathrm{H}), 0.74(\mathrm{t}, J=7 \mathrm{~Hz}, 3 \mathrm{H}) ;{ }^{13} \mathrm{C} \mathrm{NMR}\left(125 \mathrm{MHz}, \mathrm{CDCl}_{3}\right) \delta 176.3,167.2,133.7,131.6$, 128.5, 126.4 (d, $J=112 \mathrm{~Hz}), 71.6,61.7$ (d, $J=132 \mathrm{~Hz}), 56.6,49.0,35.2,33.4,31.4,28.8$, 26.6, 24.0, 22.5, 18.6, 18.0, 13.9, 12.1; IR (film) 2956, 2232, 1701, 1558, $1438 \mathrm{~cm}^{-1}$.

HRMS (EI). Calcd for $\mathrm{C}_{35} \mathrm{H}_{43} \mathrm{NO}_{2} \mathrm{P}(\mathrm{M}+\mathrm{H})^{+}:$540.3031. Found: 540.3016 .

\section{(1S, 4R)-4,7,7-Trimethyl-2-[2-(triphenylphosphanylidene)-propionyl]-2-aza-bicyclo} [2.2.1]hept-an-3-one (17a). 
A mixture of ylide $12(454 \mathrm{mg}, 1.0 \mathrm{mmol})$ and methyl iodide $(0.124 \mathrm{~mL}, 284 \mathrm{mg}, 2$ mmol, 2.0 equiv) in $2 \mathrm{~mL}$ of anhydrous acetonitrile was heated to reflux. The resulting homogeneous mixture was kept at reflux for $2 \mathrm{~h}$. After that time, the reaction mixture was cooled to room temperature, concentrated in vacuo, and the residue redissolved in 4 $\mathrm{mL}$ of dichloromethane. A $2 \mathrm{~mL}$ portion of $1 \mathrm{M}$ aqueous $\mathrm{NaOH}$ (2.0 equiv) was added and the mixture was stirred vigorously at room temperature for $2 \mathrm{~h}$. The phases were separated aqueous phase was extracted twice with $4 \mathrm{~mL}$ of dichloromethane and the combined organic phases were dried over magnesium sulfate, and concentrated in vacuo to give a solid residue. This solid residue was purified by chromatography on $\mathrm{SiO}_{2}$ with elution with $50-100 \%$ ethyl acetate in hexane) to provide $0.460 \mathrm{~g} \mathrm{(98 \% )} \mathrm{of} \mathrm{ylide} \mathrm{17a}$ as a white solid having mp $153-155{ }^{\circ} \mathrm{C}$ and the following spectral characteristics: ${ }^{1} \mathrm{H}$ NMR (400 MHz, $\left.\mathrm{CDCl}_{3}\right)^{\mathrm{TM}}$ 7.68-7.63 (m, 6H), 7.54-7.48 (m, 3H), 7.45-7.41 (m, 6H), $3.85(\mathrm{~s}, 1 \mathrm{H}), 1.91-1.88(\mathrm{~m}, 2 \mathrm{H}), 1.73-1.67(\mathrm{~m}, 1 \mathrm{H}), 1.58(\mathrm{~d}, J=16 \mathrm{~Hz}, 3 \mathrm{H}), 1.59-1.54$ $(\mathrm{m}, 1 \mathrm{H}), 1.06(\mathrm{~s}, 3 \mathrm{H}), 1.03(\mathrm{~s}, 3 \mathrm{H}), 0.86(\mathrm{~s}, 3 \mathrm{H}) ;{ }^{13} \mathrm{C} \mathrm{NMR}\left(125 \mathrm{MHz}, \mathrm{CDCl}_{3}\right){ }^{\mathrm{TM}}$ 176.6, $166.9,133.7,131.5,128.5,126.7\left(\mathrm{~d}, J_{C-P}=112 \mathrm{~Hz}\right), 65.9,55.9,49.3\left(\mathrm{~d}, J_{C-P}=139 \mathrm{~Hz}\right)$, 49.0, 30.8, 27.7, 18.8, 18.1, 13.8, 9.8; IR (film) 3058, 2959, 2233, 1709, 1558, $1438 \mathrm{~cm}^{-1}$. HRMS (EI). Calcd for $\mathrm{C}_{30} \mathrm{H}_{33} \mathrm{NO}_{2} \mathrm{P}(\mathrm{M}+\mathrm{H})^{+}: 470.2249$. Found: 470.2256.

\section{(1R, 4S)-1,7,7-Trimethyl-2-[2-(triphenylphosphanylidene)-hex-4-trans-enoyl]-2-aza- bicyclo[2.2.1]heptan-3-one (16c).}

A mixture of ylide $7(228 \mathrm{mg}, 0.5 \mathrm{mmol})$ and 1-bromo-2-butene $(0.103 \mathrm{~mL}, 135 \mathrm{mg}, 1$ mmol, 2.0 equiv) in $1 \mathrm{~mL}$ of anhydrous acetonitrile was heated to reflux. The resulting homogeneous mixture was kept at reflux for $2 \mathrm{~h}$. After that time, the reaction mixture was cooled to room temperature, concentrated in vacuo, and the residue redissolved in 2 $\mathrm{mL}$ of dichloromethane. A $1 \mathrm{~mL}$ portion of $1 \mathrm{M}$ aqueous $\mathrm{NaOH}$ (2.0 equiv) was added and the mixture was stirred vigorously at room temperature for $2 \mathrm{~h}$. The phases were separated aqueous phase was extracted twice with $2 \mathrm{~mL}$ of dichloromethane and the combined organic phases were dried over magnesium sulfate, and concentrated in vacuo to give a solid residue. This solid residue was purified by chromatography on $\mathrm{SiO}_{2}$ with elution with 50 - $100 \%$ ethyl acetate in hexane to provide $0.220 \mathrm{~g}(85 \%)$ of ylide $16 \mathrm{c}$ as a white solid having mp $164-166{ }^{\circ} \mathrm{C}$ and the following spectral characteristics: ${ }^{1} \mathrm{H} \mathrm{NMR}$ $\left(400 \mathrm{MHz}, \mathrm{CDCl}_{3}\right) \delta$ 7.69-7.63 (m, 6H), 7.54-7.47 (m, 3H), 7.46-7.40 (m, 6H), 5.35-5.32 
(m, 1H), 4.76-4.72 (m, 1H), 3.22-3.02 (m, 1H), 2.41-2.40 (m, 1H), 2.31-2.30 (m, 2H), 1.93-1.91 (m, 1H), 1.66-1.60 (m, 2H), $1.42(\mathrm{~d}, J=6 \mathrm{~Hz}, 3 \mathrm{H}), 1.33(\mathrm{~s}, 3 \mathrm{H}), 1.07(\mathrm{~s}, 3 \mathrm{H})$,

$0.86(\mathrm{~s}, 3 \mathrm{H}) ;{ }^{13} \mathrm{C}$ NMR $\left(125 \mathrm{MHz}, \mathrm{CDCl}_{3}\right) \delta 176.3,167.5,133.8,132.0,131.5,128.4$, $126.4\left(\mathrm{~d}, J_{C-P}=112 \mathrm{~Hz}\right), 122.6,71.8,59.2\left(\mathrm{~d}, J_{C-P}=134 \mathrm{~Hz}\right), 56.5,49.2,33.4,29.7,24.1$, 18.7, 18.1, 17.6, 12.1; IR (film) 3058, 2962, 2232, 1701, 1558, $1438 \mathrm{~cm}^{-1}$.

HRMS (EI). Calcd for $\mathrm{C}_{33} \mathrm{H}_{37} \mathrm{NO}_{2} \mathrm{P}\left(\mathrm{M}^{+}+\mathrm{H}\right): 510.2562$, found 510.2565

\section{(1R, 4S)-1,7,7-Trimethyl-2-[2-(triphenylphosphanylidene)-5-ethoxycarbonyl-pent-4- trans-enoyl]-2-aza-bicyclo[2.2.1]heptan-3-one (16d).}

A mixture of ylide $7(228 \mathrm{mg}, 0.5 \mathrm{mmol})$ and 1-bromo-2-butene $(0.103 \mathrm{~mL}, 135 \mathrm{mg}, 1$ mmol, 2.0 equiv) in $1 \mathrm{~mL}$ of anhydrous acetonitrile was heated to reflux. The resulting homogeneous mixture was kept at reflux for $2 \mathrm{~h}$. After that time, the reaction mixture was cooled to room temperature, concentrated in vacuo, and the residue redissolved in 2 $\mathrm{mL}$ of dichloromethane. A $1 \mathrm{~mL}$ portion of $1 \mathrm{M}$ aqueous $\mathrm{NaOH}$ (2.0 equiv) was added and the mixture was stirred vigorously at room temperature for $2 \mathrm{~h}$. The phases were separated aqueous phase was extracted twice with $2 \mathrm{~mL}$ of dichloromethane and the combined organic phases were dried over magnesium sulfate, and concentrated in vacuo to give a solid residue. This solid residue was purified by chromatography on $\mathrm{SiO}_{2}$ with elution with $50-100 \%$ ethyl acetate in hexane to provide $0.250 \mathrm{~g}(88 \%)$ of ylide $\mathbf{1 6 d}$ as a white solid having mp $153-155{ }^{\circ} \mathrm{C}$ and the following spectral characteristics: ${ }^{1} \mathrm{H}$ NMR $\left(400 \mathrm{MHz}, \mathrm{CDCl}_{3}\right) \delta$ 7.66-7.61 (m, 6H), 7.51-7.49 (m, 3H), 7.45-7.40 (m, 6H), 6.89-6.82 (m, 1H), $5.31(\mathrm{~d}, J=16 \mathrm{~Hz}, 1 \mathrm{H}), 4.09$ (q, $J=7 \mathrm{~Hz}, 2 \mathrm{H}), 3.48-3.37(\mathrm{~m}, 1 \mathrm{H}), 2.46-2.36(\mathrm{~m}$, $2 \mathrm{H}), 2.30(\mathrm{~d}, J=4 \mathrm{~Hz}, 1 \mathrm{H}), 1.97-1.87(\mathrm{~m}, 1 \mathrm{H}), 1.69-1.55(\mathrm{~m}, 2 \mathrm{H}), 1.36(\mathrm{~s}, 3 \mathrm{H}), 1.22(\mathrm{t}, J$ $=7 \mathrm{~Hz}, 3 \mathrm{H}), 1.01(\mathrm{~s}, 3 \mathrm{H}), 0.85(\mathrm{~s}, 3 \mathrm{H}) ;{ }^{13} \mathrm{C} \mathrm{NMR}\left(125 \mathrm{MHz}, \mathrm{CDCl}_{3}\right) \delta 176.6,168.0$, $166.8,152.2,133.7,131.9,128.7,126.0\left(\mathrm{~d}, J_{C-P}=113 \mathrm{~Hz}\right), 119.2,72.0,59.7,56.7(\mathrm{~d}$, $J_{C-P}=139 \mathrm{~Hz}$ ), 56.5, 49.0, 33.2, 29.9, 24.1, 18.8, 18.0, 17.6, 14.3, 12.2; IR (film) 3056, $2980,2236,1709,1644,1558,1438 \mathrm{~cm}^{-1}$.

HRMS (EI). Calcd for $\mathrm{C}_{35} \mathrm{H}_{39} \mathrm{NO}_{4} \mathrm{P}(\mathrm{M}+\mathrm{H})^{+}$: 568.2617. Found: 568.2638. 
(1R,4S)-1,7,7-Trimethyl-2-[ 2-(triphenylphosphanylidene)-3-oxo-4-methylbutanoyl]2-azabi-cyclo[2.2.1]heptan-3-one (16e).

A suspension of ylide $7(0.114 \mathrm{~g}, 0.25 \mathrm{mmol})$ in $1 \mathrm{~mL}$ of anhydrous toluene was heated until a homogeneous solution was formed. After cooling to room temperature, isobutyryl chloride (26 $(\mathrm{L}, 26.4 \mathrm{mg}, 0.25 \mathrm{mmol}, 1.0$ equiv). After the reaction mixture was stirred for 3 minutes, diisopropylethylamine (44 (L, $32.3 \mathrm{mg}, 0.25 \mathrm{mmol}, 1.0 \mathrm{eq}$ ) was added and the mixture was allowed to stir at room temperature for $0.5 \mathrm{~h}$. The resulting suspension was filtered through cotton wool and the filtrate was concentrated in vacuo to provide $0.13 \mathrm{~g}(98 \%)$ of ylide 16e as a white solid having mp $109-111^{\circ} \mathrm{C}$ and the following spectral characteristics: ${ }^{1} \mathrm{H}$ NMR $\left(400 \mathrm{MHz}, \mathrm{CDCl}_{3}\right){ }^{\text {тм }} 7.78-7.73(\mathrm{~m}, 6 \mathrm{H})$, 7.48-7.39 (m, 9H), 3.19-3.16 (m, 1H), 2.43 (d, $J=3$ Hz, 1H), 1.99-1.97 (m, 1H), 1.95$1.82(\mathrm{~m}, 1 \mathrm{H}), 1.63-1.59(\mathrm{~m}, 1 \mathrm{H}), 1.50-1.45(\mathrm{~m}, 1 \mathrm{H}), 1.39(\mathrm{~s}, 3 \mathrm{H}), 1.10(\mathrm{br} \mathrm{s}, 3 \mathrm{H}), 1.03(\mathrm{~d}$, $J=7 \mathrm{~Hz}, 3 \mathrm{H}), 0.92(\mathrm{~d}, J=7 \mathrm{~Hz}, 3 \mathrm{H}), 0.90(\mathrm{~s}, 3 \mathrm{H}) ;{ }^{13} \mathrm{C} \mathrm{NMR}\left(125 \mathrm{MHz}, \mathrm{CDCl}_{3}\right)^{\mathrm{TM}}$ 197.1, 177.4, 165.7, 133.2, 131.2, 128.3, 126.5 (d, $\left.J_{C-P}=115 \mathrm{~Hz}\right), 72.4,55.8,46.7,34.5$, 31.4 (d, $J=26 \mathrm{~Hz}$ ), 24.2, 20.9, 18.4, 18.2, 18.0, 14.1, 12.5; IR (film) 3058, 2964, 2234, $1733,1619,1543,1438 \mathrm{~cm}^{-1}$.

HRMS (EI). Calcd for $\mathrm{C}_{33} \mathrm{H}_{37} \mathrm{NO}_{3} \mathrm{P}(\mathrm{M}+\mathrm{H})^{+}:$526.2511. Found: 526.2507.

\section{(1S, 4R)-4,7,7-Trimethyl-2-[2-(triphenylphosphanylidene)-pent-4-enoyl]-2-aza- bicyclo[2.2.1] heptan-3-one (17b).}

A mixture of ylide 12 (228 mg, $0.5 \mathrm{mmol})$ and 3-bromopropene $(0.136 \mathrm{~mL}, 121 \mathrm{mg}, 1$ mmol, 2.0 equiv) in $1 \mathrm{~mL}$ of anhydrous acetonitrile was heated to reflux. The resulting homogeneous mixture was kept at reflux for $2 \mathrm{~h}$. After that time, the reaction mixture was cooled to room temperature, concentrated in vacuo, and the residue redissolved in 2 $\mathrm{mL}$ of dichloromethane. A $1 \mathrm{~mL}$ portion of $1 \mathrm{M}$ aqueous $\mathrm{NaOH}$ (2.0 equiv) was added and the mixture was stirred vigorously at room temperature for $2 \mathrm{~h}$. The phases were separated aqueous phase was extracted twice with $2 \mathrm{~mL}$ of dichloromethane and the combined organic phases were dried over magnesium sulfate, and concentrated in vacuo to give a solid residue. This solid residue was purified by chromatography on $\mathrm{SiO}_{2}$ with elution with 50 - $100 \%$ ethyl acetate in hexane to provide $0.230 \mathrm{~g}(93 \%)$ of ylide $17 \mathbf{b}$ as a white solid having mp $168-171^{\circ} \mathrm{C}$ and the following spectral characteristics: ${ }^{1} \mathrm{H}$ NMR 
(400 MHz, $\left.\mathrm{CDCl}_{3}\right) \delta$ 7.70-7.65 (m, 6H), 7.55-7.47 (m, 3H), 7.46-7.41 (m, 6H), 5.77-5.67 (m, 1H), 4.65-4.59 (m, 2H), $3.86(\mathrm{~s}, 1 \mathrm{H}), 2.99-2.88(\mathrm{~m}, 1 \mathrm{H}), 2.74-2.63(\mathrm{~m}, 1 \mathrm{H}), 1.94-$ $1.82(\mathrm{~m}, 2 \mathrm{H}), 1.72-1.65(\mathrm{~m}, 1 \mathrm{H}), 1.58-1.52(\mathrm{~m}, 1 \mathrm{H}), 1.05(\mathrm{~s}, 3 \mathrm{H}), 0.97(\mathrm{~s}, 3 \mathrm{H}), 0.85(\mathrm{~s}$, $3 \mathrm{H}) ;{ }^{13} \mathrm{C}$ NMR $\left(125 \mathrm{MHz}, \mathrm{CDCl}_{3}\right) \delta 176.9,166.8,141.9,133.8,131.6,128.4,126.7$ (d, $\left.J_{C-P}=112 \mathrm{~Hz}\right), 112.2,66.1,55.8,54.8\left(\mathrm{~d}, J_{C-P}=138 \mathrm{~Hz}\right), 49.3,31.0,27.5,18.7,18.2$, 9.8; IR (film) 3057, 2960, 2234, 1702, 1550, $1438 \mathrm{~cm}^{-1}$.

HRMS (EI). Calcd for $\mathrm{C}_{32} \mathrm{H}_{35} \mathrm{NO}_{2} \mathrm{P}(\mathrm{M}+\mathrm{H})^{+}$: 496.2405. Found: 496.2389.

\section{(1S, 4R)-4,7,7-Trimethyl-2-[2-(triphenylphosphanylidene)-5-ethoxycarbonyl-pent-4- trans-enoyl]-2-aza-bicyclo[2.2.1]heptan-3-one (17c).}

A mixture of ylide 12 (228 $\mathrm{mg}, 0.5 \mathrm{mmol})$ and ethyl 4-bromo-2-butenoate $(0.138 \mathrm{~mL}$, $193 \mathrm{mg}, 1 \mathrm{mmol}, 2.0$ equiv) in $1 \mathrm{~mL}$ of anhydrous acetonitrile was heated to reflux. The resulting homogeneous mixture was kept at reflux for $2 \mathrm{~h}$. After that time, the reaction mixture was cooled to room temperature, concentrated in vacuo, and the residue redissolved in $2 \mathrm{~mL}$ of dichloromethane. A $1 \mathrm{~mL}$ portion of $1 \mathrm{M}$ aqueous $\mathrm{NaOH}(2.0$ equiv) was added and the mixture was stirred vigorously at room temperature for $2 \mathrm{~h}$. The phases were separated aqueous phase was extracted twice with $2 \mathrm{~mL}$ of dichloromethane and the combined organic phases were dried over magnesium sulfate, and concentrated in vacuo to give a solid residue. This solid residue was purified by chromatography on $\mathrm{SiO}_{2}$ with elution with $50-100 \%$ ethyl acetate in hexane to provide $0.240 \mathrm{~g}(85 \%)$ of ylide $17 \mathrm{c}$ as a pink oil having the following spectral characteristics: ${ }^{1} \mathrm{H}$ NMR $\left(400 \mathrm{MHz}, \mathrm{CDCl}_{3}\right) \delta$ 7.70-7.63 (m, 6H), 7.54-7.47 (m, 3H), 7.46-7.42 (m, 6H), 6.88-6.81 (m, 1H), 5.38 (d, $J=16 \mathrm{~Hz}, 1 \mathrm{H}), 4.12-4.07(\mathrm{q}, J=7 \mathrm{~Hz}, 2 \mathrm{H}), 3.90(\mathrm{~s}, 1 \mathrm{H})$, 3.07-3.00 (m, 1H), 2.96-2.80 (m, 1H), 1.86-1.83 (m, 2H), 1.72-1.65 (m, 1H), 1.56-1.49 (m, 1H), 1.23 (t, $J=7 \mathrm{~Hz}, 3 \mathrm{H}), 1.04$ (s, 3H), 0.93 (s, 3H), 0.85 (s, 3H); ${ }^{13} \mathrm{C}$ NMR $(125$ $\left.\mathrm{MHz}, \mathrm{CDCl}_{3}\right) \delta 177.1,166.9,152.4,133.7,132.0,131.8,128.6,126.3\left(\mathrm{~d}, J_{C-P}=113 \mathrm{~Hz}\right)$, 119.0, 65.9, 59.7, 55.9, 53.3 (d, $\left.J_{C-P}=142 \mathrm{~Hz}\right), 49.3,30.5,30.0,27.5,18.6,18.1,14.3$, 9.8; IR (film) 3057, 2960, 2234, 1716, 1558, $1438 \mathrm{~cm}^{-1}$.

HRMS (EI). Calcd for $\mathrm{C}_{35} \mathrm{H}_{39} \mathrm{NO}_{4} \mathrm{P}(\mathrm{M}+\mathrm{H})^{+}:$568.2617. Found: 568.2632. 
(1S, 4R)-4,7,7-Trimethyl-2-[2-(triphenylphosphanylidene)-5-trimethylsilyl-pent-4ynoyl]-2-aza-bicyclo[2.2.1]heptan-3-one (17d).

A mixture of ylide $12(228 \mathrm{mg}, 0.5 \mathrm{mmol})$ and 3-bromo-1-TMS-1-propyne $(0.170 \mathrm{~mL}$, $229 \mathrm{mg}, 1 \mathrm{mmol}, 2.0$ equiv) in $1 \mathrm{~mL}$ of anhydrous acetonitrile was heated to reflux. The resulting homogeneous mixture was kept at reflux for $2 \mathrm{~h}$. After that time, the reaction mixture was cooled to room temperature, concentrated in vacuo, and the residue redissolved in $2 \mathrm{~mL}$ of dichloromethane. A $1 \mathrm{~mL}$ portion of $1 \mathrm{M}$ aqueous $\mathrm{NaOH}(2.0$ equiv) was added and the mixture was stirred vigorously at room temperature for $2 \mathrm{~h}$. The phases were separated aqueous phase was extracted twice with $2 \mathrm{~mL}$ of dichloromethane and the combined organic phases were dried over magnesium sulfate, and concentrated in vacuo to give a solid residue. This solid residue was purified by chromatography on $\mathrm{SiO}_{2}$ with elution with $50-100 \%$ ethyl acetate in hexane to provide $0.270 \mathrm{~g}(95 \%)$ of ylide $17 \mathrm{~d}$ as a white solid having $\mathrm{mp} 169-172^{\circ} \mathrm{C}$ and the following spectral characteristics: ${ }^{1} \mathrm{H}$ NMR $\left(400 \mathrm{MHz}, \mathrm{CDCl}_{3}\right) \delta$ 7.73-7.67 (m, 6H), 7.52-7.48 (m, $3 \mathrm{H}), 7.44-7.40(\mathrm{~m}, 6 \mathrm{H}), 3.88(\mathrm{~s}, 1 \mathrm{H}), 3.26-3.16\left(\mathrm{dd}, J_{1}=23 \mathrm{~Hz}, J_{2}=19 \mathrm{~Hz}, 1 \mathrm{H}\right), 2.87-$ $2.78\left(\mathrm{dd}, J_{1}=19 \mathrm{~Hz}, J_{2}=17 \mathrm{~Hz}, 1 \mathrm{H}\right), 2.02-1.94(\mathrm{~m}, 1 \mathrm{H}), 1.88-1.85(\mathrm{~m}, 1 \mathrm{H}), 1.69-1.66$ (m, 1H), 1.61-1.58 (m, 1H), $1.04(\mathrm{~s}, 3 \mathrm{H}), 1.03(\mathrm{~s}, 3 \mathrm{H}), 0.85(\mathrm{~s}, 3 \mathrm{H}),-0.03(\mathrm{~s}, 9 \mathrm{H}) ;{ }^{13} \mathrm{C}$ NMR (125 MHz, $\left.\mathrm{CDCl}_{3}\right) \delta 176.8,166.3,133.8,131.6,128.5,126.1$ (d, $\left.J_{C-P}=113 \mathrm{~Hz}\right)$, 110.6, 66.1, 55.9, $53.0\left(\mathrm{~d}, J_{C-P}=145 \mathrm{~Hz}\right), 49.1,30.7,27.5,18.8,18.2,17.8,9.8,0.1$; IR (film) $3057,2958,2360,2163,1708,1558,1438 \mathrm{~cm}^{-1}$.

HRMS (EI). Calcd for $\mathrm{C}_{35} \mathrm{H}_{41} \mathrm{NO}_{2} \mathrm{PSi}(\mathrm{M}+\mathrm{H})^{+}:$566.2644. Found: 566.2656.

\section{(1S, 4R)-4,7,7-Trimethyl-2-[2-(triphenylphosphanylidene)-3-tert-butoxycarbonyl- propionyl]-2-aza-bicyclo[2.2.1]heptan-3-one (17e).}

A mixture of ylide $12(228 \mathrm{mg}, 0.5 \mathrm{mmol})$ and $t$-butyl bromoacetate $(0.148 \mathrm{~mL}, 195$ $\mathrm{mg}, 1 \mathrm{mmol}, 2.0$ equiv) in $1 \mathrm{~mL}$ of anhydrous acetonitrile was heated to reflux. The resulting homogeneous mixture was kept at reflux for $2 \mathrm{~h}$. After that time, the reaction mixture was cooled to room temperature, concentrated in vacuo, and the residue redissolved in $2 \mathrm{~mL}$ of dichloromethane. A $1 \mathrm{~mL}$ portion of $1 \mathrm{M}$ aqueous $\mathrm{NaOH}(2.0$ equiv) was added and the mixture was stirred vigorously at room temperature for $2 \mathrm{~h}$. The phases were separated aqueous phase was extracted twice with $2 \mathrm{~mL}$ of 
dichloromethane and the combined organic phases were dried over magnesium sulfate, and concentrated in vacuo to give a solid residue. This solid residue was purified by chromatography on $\mathrm{SiO}_{2}$ with elution with $50-100 \%$ ethyl acetate in hexane to provide $0.260 \mathrm{~g}(91 \%)$ of ylide 17e as a low melting solid having the following spectral characteristics: ${ }^{1} \mathrm{H}$ NMR $\left(400 \mathrm{MHz}, \mathrm{CDCl}_{3}\right) \delta$ 7.74-7.64 (m, 6H), 7.56-7.50 (m, 3H), 7.49-7.41 (m, 6H), 3.86 (s, 1H), 3.30-3.00 (br s, 1H), 2.90-2.65 (br s, 1H), 1.92-1.84 (m, $1 \mathrm{H}), 1.71-1.64(\mathrm{~m}, 1 \mathrm{H}), 1.58-1.52(\mathrm{~m}, 1 \mathrm{H}), 1.48-1.40(\mathrm{~m}, 1 \mathrm{H}), 1.26(\mathrm{~s}, 9 \mathrm{H}), 1.04(\mathrm{~s}, 3 \mathrm{H})$, $0.96(\mathrm{~s}, 3 \mathrm{H}), 0.84(\mathrm{~s}, 3 \mathrm{H}) ;{ }^{13} \mathrm{C} \mathrm{NMR}\left(125 \mathrm{MHz}, \mathrm{CDCl}_{3}\right) \delta 176.8,174.1,167.2,133.9$, 132.0, 131.6, 128.5, $126.3\left(\mathrm{~d}, J_{C-P}=113 \mathrm{~Hz}\right), 79.1,66.2,55.8,51.5\left(\mathrm{~d}, J_{C-P}=148 \mathrm{~Hz}\right)$, 49.2, 33.5, 30.6, 27.9, 27.4, 18.6, 18.1, 9.8; IR (film) 3058, 2964, 2231, 1716, 1558, 1438 $\mathrm{cm}^{-1}$.

HRMS (EI). Calcd for $\mathrm{C}_{35} \mathrm{H}_{41} \mathrm{NO}_{4} \mathrm{P}(\mathrm{M}+\mathrm{H})^{+}:$570.2773. Found: 570.2789 .

Condensation of Ylides 7, 12, 16a, 17a with Aldehydes: Preparation of Unsaturated Carbonyl Compounds 19, 25.

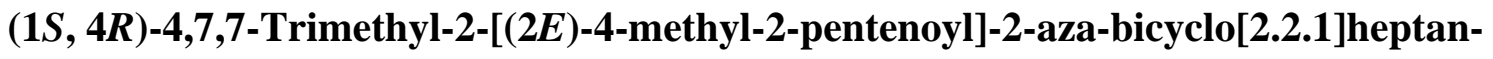
3-one (19).

A solution of $341 \mathrm{mg}$ ( $0.75 \mathrm{mmol}, 1.5$ equiv) of ylide 12 and isobutyraldehyde (47 $\mu \mathrm{L}, 37 \mathrm{mg}, 0.5 \mathrm{mmol}$ ) in anhydrous $\mathrm{ClCH}_{2} \mathrm{CH}_{2} \mathrm{Cl}$ was heated at $\sim 83^{\circ} \mathrm{C}$ in a sealed tube until no aldehyde could be detected by TLC analysis $(4 \mathrm{~h})$. The reaction mixture was cooled to room temperature and concentrated in vacuo to provide crude oily products. The oily residue was purified by chromatography on $\mathrm{SiO}_{2}$ with elution by $5 \%$ ethyl acetate in hexane to provide $112 \mathrm{mg}(90 \%)$ of unsaturated imide 19 as a colorless oil having the following spectral characteristics: ${ }^{1} \mathrm{H}$ NMR $\left(400 \mathrm{MHz}, \mathrm{CDCl}_{3}\right) \delta 7.13(\mathrm{~d}, J=$ $16 \mathrm{~Hz}, 1 \mathrm{H}), 7.06\left(\mathrm{dd}, J_{1}=16 \mathrm{~Hz}, J_{2}=6 \mathrm{~Hz}, 1 \mathrm{H}\right), 4.31(\mathrm{~d}, J=2 \mathrm{~Hz}, 1 \mathrm{H}), 2.51-2.46(\mathrm{~m}$, 1H), 1.97-1.94 (m, 1H), 1.81-1.75 (m, 1H), 1.63-1.56 (m, 2H), $1.05(\mathrm{~s}, 3 \mathrm{H}), 1.03(\mathrm{~s}, 3 \mathrm{H})$, $1.02(\mathrm{~s}, 3 \mathrm{H}), 0.91(\mathrm{~d}, \mathrm{~J}=2 \mathrm{~Hz}, 6 \mathrm{H}) ;{ }^{13} \mathrm{C} \mathrm{NMR}\left(125 \mathrm{MHz}, \mathrm{CDCl}_{3}\right) \delta 178.8,165.2,156.3$, 120.0, 63.7, 56.5, 47.2, 31.3, 30.4, 26.7, 21.2, 18.5, 17.7, 9.5; IR (film) 2964, 2873, 1746, $1678,1634,1455 \mathrm{~cm}^{-1}$. 
HRMS (EI). Calcd for $\mathrm{C}_{15} \mathrm{H}_{24} \mathrm{NO}_{2}(\mathrm{M}+\mathrm{H})^{+}: 250.1807$. Found: 250.1802 .

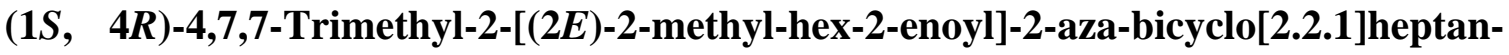
3-one (24).

A solution of $93.9 \mathrm{mg}$ ( $0.2 \mathrm{mmol}, 1.5$ equiv) of ylide 17a and $n$-butyraldehyde (12.1 $\mu \mathrm{L}, 9.62 \mathrm{mg}, 0.13 \mathrm{mmol}$ ) in anhydrous $\mathrm{CH}_{2} \mathrm{Cl}_{2}$ was heated at $47^{\circ} \mathrm{C}$ in a sealed tube until no aldehyde could be detected by TLC analysis $(47 \mathrm{~h})$. The reaction mixture was cooled to room temperature and concentrated in vacuo to provide crude oily products. The oily residue was purified by chromatography on $\mathrm{SiO}_{2}$ with elution by $5 \%$ ethyl acetate in hexane to provide $46.4 \mathrm{mg}$ (88\%) of unsaturated imide 24 as a colorless oil having the spectral characteristics: ${ }^{1} \mathrm{H}$ NMR $\left(400 \mathrm{MHz}, \mathrm{CDCl}_{3}\right)^{\mathrm{TM}}$ 6.00-5.97 (m, 1H), $4.14(\mathrm{~d}, J=2$ Hz, 1H), 2.14 (q, $J=7$ Hz, 2H), 2.03-1.98 (m, 1H), 1.86 (s, 3H), 1.83-1.71 (m, 2H), 1.61$1.52(\mathrm{~m}, 1 \mathrm{H}), 1.50-1.44(\mathrm{~m}, 2 \mathrm{H}), 1.05(\mathrm{~s}, 3 \mathrm{H}), 0.99(\mathrm{~s}, 3 \mathrm{H}), 0.95(\mathrm{t}, J=7 \mathrm{~Hz}, 3 \mathrm{H}), 0.94$ (s, 3H); ${ }^{13} \mathrm{C}$ NMR (125 MHz, $\mathrm{CDCl}_{3}$ ) ${ }^{\text {тм }} 177.4,171.3,138.4,132.0,64.9,56.3$, 47.4, 30.7, 30.2, 26.6, 21.7, 18.6, 17.7, 13.8, 13.4, 9.6; IR (film) 2962, 2873, 1750, $1671 \mathrm{~cm}^{-1}$.

HRMS (EI). Calcd for $\mathrm{C}_{16} \mathrm{H}_{26} \mathrm{NO}_{2}(\mathrm{M}+\mathrm{H})^{+}$: ): 264.1964. Found: 264.1958.

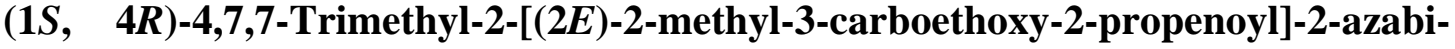
cyclo[2.2.1]heptan-3-one (25).

A solution of $137 \mathrm{mg}$ ( $0.3 \mathrm{mmol}, 1.5$ equiv) of ylide 12 and ethyl glyoxalate (20.4 mg, $0.2 \mathrm{mmol}$ ) in anhydrous toluene was heated at $100^{\circ} \mathrm{C}$ in a sealed tube until no aldehyde could be detected by TLC analysis $(21 \mathrm{~h})$. The reaction mixture was cooled to room temperature and concentrated in vacuo to provide crude oily products. The oily residue was purified by chromatography on $\mathrm{SiO}_{2}$ with elution by $5 \%$ ethyl acetate in hexane to provide $53.0 \mathrm{mg}(90 \%)$ of unsaturated imide 25 as a colorless oil having the following spectral characteristics: ${ }^{1} \mathrm{H}$ NMR $\left(400 \mathrm{MHz}, \mathrm{CDCl}_{3}\right) \delta 5.80(\mathrm{~s}, 1 \mathrm{H}), 4.20(\mathrm{~d}, J=2 \mathrm{~Hz}$, $1 \mathrm{H}), 4.15$ (q, $J=7 \mathrm{~Hz}, 2 \mathrm{H}), 2.28$ (s, 3H), 2.00-1.97 (m, 1H), 1.85-1.78 (m, 1H), 1.65-1.57 (m, 2H), 1.25 (t, $J=7 \mathrm{~Hz}, 3 \mathrm{H}), 1.03$ (s, 3H), 0.95 (s, 3H), 0.93 (s, 3H); ${ }^{13} \mathrm{C}$ NMR (125 $\left.\mathrm{MHz}, \mathrm{CDCl}_{3}\right) \delta 177.5,169.0,165.5,150.9,120.0,64.0,60.3,56.0,47.7,30.4,26.7,18.6$, 17.6, 15.8, 14.2, 9.3; IR (film) 2966, 1754, 1718, $1678 \mathrm{~cm}^{-1}$. 
HRMS (EI). Calcd for $\mathrm{C}_{16} \mathrm{H}_{24} \mathrm{NO}_{4}(\mathrm{M}+\mathrm{H})^{+}: 294.1705$. Found: 294.1700 .

\section{References}

1. Noguchi, H.; Aoyama, T.; Shioiri, T. Heterocycles 2002, 58, 471-504.

2. $\quad$ Cheng, P. T. W.; Chen, S.; Devasthale, P.; Ding, C. Z.; Herpin, T. F.; Wu, S.; Zhang, H.; Wang, W.; Ye, X.-Y.; (Bristol-Myers Squibb Company, USA). Application: WO WO, 2004, p 543 pp. 